\title{
Terrorist Threats on the Economic System and Combating Financing Terrorist Organizations
}

\author{
Gheorghe Cosmin MANEA \\ Bucharest University of Economic Studies, Bucharest, Romania \\ maneacosmin37@gmail.com \\ Cristian Valeriu PAUN \\ Bucharest University of Economic Studies, Bucharest, Romania \\ cristian.paun@rei.ase.ro
}

PICBE | 920

\begin{abstract}
The complexity of the current economic development environment in Europe, as a result of the extremist-terrorist phenomenon, coupled with the accentuation of the economic and technological differences among the world's states, has generated and continues to generate new risks and threats to the communities of people. The attack on civilian targets in Europe, by members of criminal groups has resulted in casualties within human communities. Because some terrorist-extremist organizations are criminal groups that have a specific organization, logistics, specific training and education systems that cannot work without having material and financial resources. As a result, one of the most effective ways to fight the threat of terrorist organizations is to combat terrorism financing.
\end{abstract}

Keywords: terrorist organizations, economic development, financial fraud, financing of terrorism, Europe, international Organizations.

\section{Introduction}

As a result of the terrorist attacks committed by Osama Bin Laden's Al Qaeda network on September 11, 2001, the need for wider and wider monitoring of the source of financial resources obtained by international terrorist organizations was evident. This is because such resources are, first of all, the vital force to maintain these active groups, and secondly, a determining factor for the scale of their actions.

From this point of view, the control and monitoring of financial operations have been intensified within the United Nations, and terrorist financing has been included as one of the functions of the Financial Action Task Force (FATF), an international UN body responsible for identifying and the neutralization of money laundering. In addition to monitoring Member States' compliance with the 40 recommendations made by the FATF in 1990, they were revised and updated in 2003.

It is known that a significant part of these resources comes from money laundering, the international financial system and deposits in tax havens. Earlier, the focus has been on transnational criminal organizations, especially those involved in drug trafficking and arms and human trafficking, in addition to the activities of mafia operations, which have operated large amounts of money from illicit activities such as kidnapping, extortion, piracy, sexual exploitation and drug trafficking.

Money laundering or, as popularized by lawmakers, money laundering is, according to Lima (2014, p. 281), a complex system requiring permanent monitoring. Their effectiveness depends on an integrated effort of the Member States through the exchange 
between intelligence agencies and financial intelligence units, accompanied by the interest and support of governments in identifying their origin and destination.

This cooperation takes place with the participation of institutions that are linked to the national and international financial system, being considered the most sensitive and vulnerable to manipulation, providing data and information on financial transactions over certain values that will be analyzed.

PICBE | 921

However, increased opportunities for hiding illicit financial resources have been made available on the world market. According to Naim (2006, p. 128), countries have opened up their economies, regulated financial systems and allowed domestic financial systems, commercial and investment banks, stock exchanges, brokerage agencies to join partners in other countries. This, in the author's opinion, has created more difficult to monitor and regulate operating and control structures than when the finances were administered locally.

In this context, new information and communication technologies have been added with a relevant role in the transformation of the international financial market, especially in the case of online transfers that travel daily through the internet to tax havens. In addition to a considerable reduction in transaction costs, they allow for the secrecy and values of the operator to be maintained, while financial intelligence agencies prevent them from identifying the origin of these funds due to their extraterritorial nature.

Given the scope and relevance of the subject, and the decisive contribution to maintaining a comprehensive security situation in the face of the threat of international terrorism, what I propose in this article is to present how the international terrorist financing system is being developed within the Organization United Nations to reduce or neutralize such actions.

A second objective is the pursuit of reflection to analyze possible defects in this process, as we have seen during this period the consolidation of terrorist-extremist groups and, therefore, they have led to terrorist actions in several countries, especially Europe.

\section{International terrorism}

Terrorism is an old phenomenon in societies long before the invasion or guilds of the French Revolution, although in this episode, according to Vedantam $(2008$, p. 8), expression has been popularized and recommended as a systematic action to achieve state goals. Its origins date back to the third century $\mathrm{BC}$, quoted in several passages of biblical text, especially in the Old Testament. Evidence shows that in 48 BC Zealot, a group of radical Jewish extremists who radically opposed the Roman domination, began an insurgency movement using terrorist actions.

Since then, it has been used so far, either as a liberation struggle, where nationalist groups, armed as the Irish Republican Army (IRA), the Basque Country and Liberty (ETA), the Red Brigades and Baader- Meinhof, all of which appear in time and give the form of another type of terrorism manifested by other groups in the religious-extremist recourse of al-Qaida, the Taliban (Afghanistan), The Boko Haram (Nigeria) and the most large and more organized, ISIS (the Islamic State of Iraq and Syria), also known as the Islamic army, among others.

It must be said that there are at least two major differences in the subject of terrorism. The first is in the relationship between its definition, because there is no concept with a 
consensus unanimously accepted by all member states of the United Nations, and in this sense one can say that each has its own definition. The second is the controversy that it is an external threat, therefore a war, in the struggle with the armed forces that defend the US and its partners in NATO, or an internal threat, and the issue of public safety as assessed in the European Union.

According to Cretella Neto (2007, p.711), the difficulty in drawing up a consensual definition has important consequences, among them, preventing the introduction of the list of offenses under the responsibility of the International Criminal Court Statute, or even receiving the benefits of the Geneva Convention treatment of prisoners of war.

Lyman and Potter $(2007$, p.326) conceives it as a serious violence committed by any means which causes the death, injury or serious deterioration of property against innocent people in order to cause such consequences, directly or indirectly, and by constraining or intimidating specific or governmental groups or other similar political, military, religious or philosophical benefits, and without any justification or excuse.

For the Federal Bureau of Investigation (FBI) is the illegal use of force or violence against persons or property to intimidate or constrain a government, civilian population or any of its segments in order to pursue political goals or social issues.

Within the United Nations, terrorism is considered to be criminal acts, including against civilians, acts committed to cause death or serious bodily injury or hostage, in order to provoke a state of terror among the general public or in a group to intimidate a population or to force a government or an international organization to practice or stop the practice of any act.

Previously, the UN Security Council issued Resolution no. 1373 of 28 September 2001, which considers that all acts of terrorism pose a threat to international peace and security. The purpose of this political action was to internationalize anti-terrorist and counterterrorism actions involving all Member States, including co-operation treaties to identify and neutralize financial resources to fund them.

\section{Organization \&resources and pre-bombarded costs}

The assets of terrorist groups are estimated to be significant and, in some cases, exceed the military budget of many developing countries with millions of dollars. It is worth remembering that virtually all groups develop assistive and philanthropic activities in their regions, characterized by extreme poverty of the population and bankruptcy of local governments.

Such activities serve as a pretext for encouraging and facilitating money donation with the sympathy of international public opinion for humanitarian causes. However, some of these resources are diverted for warlike purposes, financing the logistics of attacks, recruitment, advertising and buying weapons.

Although terrorist attacks are relatively low compared to economic and psychological damage, the most important investments are meant to keep active and fully operational groups.

Villamarin (2006, p.144) warns that World Bank estimates indicate that they are constantly circulating on international economic markets between $\$ 600$ billion and $\$ 700$ billion from drug trafficking in search of legalizing the aggravating circumstance that part of these funds are destined to finance terrorist groups in Africa and the Middle East. 
In Dallagnol's lesson (2011, p.370), terrorist networks need financial resources for different needs, such as: a) promotion of ideology, including through charity organizations, schools, political parties and media publications; operative members and their families, c) recruitment of new members, d) travel arrangements, e) internal travel expenses (buying or renting houses, cars), f) the cost of forming members, g) falsification or purchase documents b) payment of bribes, h) purchase of equipment, weapons, munitions and explosives, i) purchase of goods for its members, j) communication expenses, l) maintenance of training grounds, and $\mathrm{m}$ ) expenses for terrorist relatives killed in action .

In any case, because of the volume of money traded, terrorist groups have developed into an administration similar to that of private companies, because its success depends on the financial management that will allow its growth and future operations.

\section{Origin of resources}

The origin of resources that allow terrorist groups to act does not come exclusively from money laundering.

Bechara and Manzano (2009, p.176) argue that terrorist financing sources are criminal activities, donations and charitable contributions, legitimate or quasi-legitimate business, and sponsorship of states or governments. However, according to the authors, there are basically two primary sources, one internal and one external.

Internally, it is similar to the method used by mafia and transnational criminal organizations. These resources are generated by the mandatory taxation of the population and companies, paid for redemption in human and merchant abductions and profits in the trade and trafficking of drugs, the sale of opium in Afghanistan, etc.

Schmid (2007) also adds voluntary contributions of sympathetic individuals, migrant communities from the diaspora, and social and religious organizations, in the latter case, aimed at philanthropy.

Outwardly, they are obtained through donations from states with political and economic interests, sympathizers, community members, or expatriates. Traditional group practice is the money transfer between them, especially when funding lines are detected and cut by financial intelligence agencies and other international bodies.

Regarding the Islamic Army, in particular, some of the funds are internal, adding looting from Iraqi banks located in areas under the control of the group and illegal oil trade in the cities conquered and robbed in Iraq and Syria.

On the other hand, it should be noted that some measures adopted after September 11 contributed to the partial weakening of fundraising for these groups. These include stricter control and surveillance rules than international financial markets in several countries.

Such measures have led to a considerable increase in the need for financial resources to maintain terrorist actions, as previous possibilities were no longer available. However, these measures have led to new forms of fundraising by terrorist networks, including the use of digital communications and the corruption of financial market actors.

\section{Evolution of illicit financial processes}

Classically, the first manifestation of this criminal typology came from the Banking Supervisory Committee established in 1988 and composed of representatives of the 13 most 
industrialized countries, although its recommendations and declarations did not have binding and judicial force.

The Basel Declaration, developed by the Committee, has created the doctrinal and conceptual framework that will be improved and strengthened in the years to come, especially in the role of the banking system and various financial entities in combating money laundering.

The United Nations Convention against Illicit Traffic in Narcotic Drugs and Psychotropic Substances, which took place in Vienna the same year, would treat the problem as a secondary offense as a related crime. However, for the first time, there will be an obligation to criminalize such behavior on the international scene, in addition to the ban on banking secrecy.

Still under the influence of the Basel Committee and the initiative of the Group of the seven most industrialized countries, in 1989 the Financial Action Task Force (FATF), an intergovernmental institution that examined, developed and promote measures to prevent and combat money laundering.

It is the body responsible for developing international control policies to identify and neutralize money laundering operations in the international financial system, as well as overseeing Member States' compliance with the recommendations.

This important body annually publishes a list of non-cooperative countries and territories that have not committed themselves to combating money laundering.

In 1990, the FATF will launch a set of 40 recommendations containing the countries' action strategy to address this issue, which will be reviewed and updated in 1996 and 2003 and is currently in force with the accession of 130 countries as members of the United Nations.

It is worth noting Recommendation 26, which suggests that all Member States create financial intelligence units (FIUs) as a criminal instrument with the task of receiving, analyzing and disseminating suspicious transaction reports. In Brazil, the Financial Activities Control Board (COAF) was set up, an entity linked to the Ministry of Finance for this purpose. After September 11th, the FATF will extend this control to the financing of terrorism.

In 1995, the Egmont Group was created at the initiative of the Financial Intelligence Unit in Belgium and the US, where several FIUs have begun working together in an informal organization that provides a network of cooperation between countries through financial intelligence units calls (FIU). The purpose of this group is to promote a forum to increase support for national anti-money laundering programs in its countries, including Brazil, hosted by the Group in 1999.

This support includes expanding cooperation between the FIU and systematizing the exchange of experience and information on financial information, improving the capacity and expertise of unit staff and generating better communication through the application of specific technologies.

The year 2000 is considered, in particular, as a milestone in the financing of terrorism through two major initiatives adopted by the United Nations. The first is the United Nations Convention Against Organized Crime, known as the Palermo Convention, which would deepen the issue of criminalization of money laundering, which is characterized as transnational, beyond recognizing the competence of Member States to know these transactions even outside their territories, and the second is the International Convention for the Suppression of Terrorist Financing. 
In this regard, the United Nations Security Council has a role to play in approving various treaties and resolutions aimed at mitigating terrorist financing practices. The main documents drawn up include Resolution no. 1.540 of 28 April 2004, which reported a ban on financial services for the transfer and export of such weapons of mass destruction and their means of delivery and material or any other form of financial support to organizations or persons related to this type of trade.

Also in 2004, the FATF launches a set of nine special recommendations on terrorism financing, combining 40 existing money laundering, which is the basic framework for detecting, preventing and suppressing terrorism and terrorist groups.

Santos (2014, p. 52) states that the subjects are structured as follows:

(I) the ratification and implementation of United Nations instruments; II) incriminating terrorist financing and money laundering; (III) the freezing and confiscation of terrorist goods; (IV) the intermediary communication of suspected terrorist operations; (v) international cooperation; (VI) alternative shipments; (VII) electronic transfers; (VIII) nonprofit entities and; (IX) cash transfer services.

Paragraph (10) reiterates the importance of all States to identify and, if necessary, establish appropriate procedures to fully implement all aspects of the measures described in paragraph 1 and strongly urges all Member States to implement international standards Comprehensive Financial Action Task Force '(FATF), and in particular Recommendation 6 on selective sanctions on terrorism and its financing;

The Financial Action Task Force (FATF), in particular Recommendation 6 on selective sanctions on terrorism and its financing;

Paragraph (11) Strongly urges the Member States to apply the FATF Interpretative Note to Recommendation 6 and to take note, among other things, of best practices for the effective implementation of, and financing of, selective financial sanctions related to terrorism, and notes the need for States have appropriate legal authorities and procedures in place to enforce and enforce selective financial penalties irrespective of the legal process, to take "reasonable" or "reasonable" evidence, and to have the ability to collect or request as much information as possible from all relevant sources;

Paragraph (12) Calls on the Member States to act firmly and decisively on the disruption of flows of funds and other financial assets and economic resources to natural and legal persons in the Al-Qaeda sanctions list as referred to in paragraph 1 (a), and taking into account relevant FATF recommendations and international standards established to prevent the misuse of non-profit organizations, informal / alternative remittance systems and physical cross-border cash flow, as it seeks to mitigate the impact on legitimate activities pursued by these means.

Most recently, in 2015, Resolution no. 2199 of 12 February 2015, which recommends strengthening the mechanisms against those financing international terrorist groups, referring in particular to the Islamic state of the terrorist group which, as already mentioned, has significant revenues from oil and antique trade.

Most recently, in 2015, Resolution no. 2199 of 12 February 2015, which recommends strengthening the mechanisms against those financing international terrorist groups, referring in particular to the Islamic state of the terrorist group which, as already mentioned, has significant revenues from oil and antique trade. 


\section{Definitions of Money Laundering Crime}

In the matter of terrorism, money laundering is considered a directly related crime. By common sense, money laundering is understood as masking and concealing the origin of the values and assets obtained with illicit activities introduced into the financial economic system with an appearance of legality. This perception is somewhat consensual in the academic field.

Maia (2004, p. 53) defines the expression "the complex of operations integrated through the stages of transformation, dissimulation and integration of goods, rights and values in order to make legitimate goods derived from criminal offenses."

In Welter's lesson (2001, p. 147), it is a process by which the illicit origin of certain goods is hidden for their introduction into the legal market. "

According to the COAF, it is defined as the process by which offenders convert assets obtained in illegal activities into assets with an apparently legal origin. This practice often involves multiple transactions, used to hide the source of financial assets and allow them to be used without compromising the criminals.

This whole process, involving a certain complexity, is divided, according to international doctrine, into three stages: placement, hiding and integration, followed in the same order and occurring simultaneously.

These steps are explained in the framework of the Money Laundering Program: a global issue developed by the United Nations International Drug Control Program in collaboration with the COAF.

In the document, these steps are explained as follows:

1) Bank deposits are made in placement, the purchase of goods or products immediately after the commission of the illicit activities, in which the agent will try to move on the economic market, the resources obtained with these activities. Generally, money is framed to avoid identifying the origin, and commercial units that work with money in kind are used. Interestingly, agencies at this stage are looking for countries where laws are nonexistent or flexible, or control efforts are not strong enough to identify and arrest those involved. It is considered the most dangerous stage, as money is still close to its origins.

2) Hidden, agents try to hinder the bookkeeping, breaking a chain of evidence before they can investigate the origin of resources and the need to prove their origin. In this sense, they transfer money electronically, transferring assets to anonymous accounts or making deposits in ghost accounts.

3) In the process of integration, assets are formally embedded in the economic system where criminal organizations are trying to invest in businesses such as hotels, nightclubs, restaurants, service providers, the construction industry, commerce in general, electronic games, among others activities that facilitate the legalization of illegal money. They can be used to acquire legitimate companies that could support future illegal operations and encourage criminal activity.

On the other hand, money laundering techniques are complex and diverse. The international doctrine highlights a catalog of the most widely used 17 techniques for getting the first electronic placement online transfers. This involves the use of the electronic communications network, banks, or companies that are dedicated to the transfer of 
commercial funds to carry the crime product from one place to another with a minimum detection margin.

\section{The tax havens}

A significant amount of money laundering takes place in so-called tax havens, established in countries or territories that do not tax on income or make the maximum rate lower than $20 \%$, or even those whose internal legislation imposes confidentiality on the composition of corporate property of legal persons or their property.

In this sense, Gomes (2009, p.135) states that there are free countries of political or zero tax exemptions to attract foreign investment, especially importers and exporters, but ending up by generating permissive legislation and financial collar crimes white because it is weak in terms of financial controls and tax and rigid requirements on banking secrecy, generating privacy, security and protection.

In Villaran's opinion (2009, p.45), these countries emerged at the beginning of the 20th century, led by the Cold War, and promoted by the great powers, such as the protection of private and private property, to rise to the danger of communism Soviet Union.

According to the author, they started on the European continent with the main attractions being Luxembourg, Andorra, Liechtenstein and Monaco. In the Caribbean region, it cites the Cayman Islands, the Bahamas and the Virgin Islands. In Central America, Panama and Costa Rica. In Asia, Singapore, Hong Kong and Macao and in the Middle East, Lebanon and Bahrain. Subsequently, other countries have been inserted or removed from this list.

Generally, tax havens have no resources other than tourism, and perhaps for this reason they provide tax and financial facilities in a secret way to seek out foreign investment. They are rarely used for criminal purposes, mainly in the financing of terrorist networks that take advantage of the secrecy and ease of handling illicit money.

The biggest facility is without a doubt the possibility of money laundering, because in many of these places there is an absolute banking and professional secret, actions by the bearer of companies that can prevent the identification of those who are behind the transaction and other mechanisms to "camouflage "money of unlawful origin.

Among the most common actions are various financial and commercial frauds with money sent to offshore companies, phantom institutions and banking institutions with similar names, with major international institutions, but which has nothing to do with them and they are shelter for the capital used for criminal purposes.

Another attractive feature of these operations is the institutional situation of these countries, which, as already mentioned, had condemned governments, fragile legislation and inoperative police.

Naim (2006, p.134-135) cites some examples and characteristics that identify these countries: Cayman Islands, which has approximately 45,000 inhabitants and nearly 600 branch branches, or triple the Brazil-Paraguay-Argentina border, more precisely in Ciudad Del It is, Paraguay, with 300 thousand inhabitants and has 55 branches, and in 1997 it has reached 45 billion dollars.

There are just as many as the Nauru state in the South Pacific, with about 12,000 inhabitants and forty thousand registered companies.

The entry of these resources is operationalized by offshore companies, which, according to the Gomes teachings (2009, p.136), are companies outside the borders of a 
country and remain protected by the tax rules of the country in which they operate, allowing for the introduction of cash without clarifying the origin.

In 1998, the Organization for Economic Cooperation and Development (OECD) adopted four basic characteristics for identifying a tax haven.

These are non-existent taxation, a lack of effective information exchange, a lack of legal or administrative transparency, and a lack of an obligation on companies to carry out substantial economic activity. Indeed, the dynamics of this whole process, together with the ever closer relations between terrorist organizations and criminal organizations that act against the corruption of public and private agents, radically changed the traditional method of storing and transferring resources to tax havens.

Saviano (2014, p.272) alludes to this situation when he states that today, New York and London are the two big dirty money launchers in the world. There are no tax havens, Cayman Islands or Man Island, but London and Wall Street. Such a statement is particularly important when the US and its allies require more rigorous control of financial flows from their territories to other Member States.

\section{The role of new digital technologies}

New information technologies, especially electronic and online communications, are considered by many scientists and researchers to be an extraordinary revolution, perhaps the biggest one we have gone through, capable of completely changing human status in any way.

In this respect, Castells (2003, p. 56) already warned that the correct use of the Internet has become a key source of productivity and competitiveness for businesses of all kinds, especially for the financial market.

The interdependence of these markets and the hybrid nature of their derivative instruments, often made up of securities of different origins, encompass them at a rapid pace.

However, we can see that the role of these digital technologies has been paradoxical. On the one hand, it allowed for greater inclusion and interaction of societies, access to broader knowledge and the expansion of culture, on the other, potentiating new global threats with the emergence of digital offenses.

These threats include facilitating the financing of international terrorism through online transfers and fundraising on social networks, as reported by the FATF, which has led to a special recommendation 7 , the content of which includes including correct information such as name, address and account number, as well as the need for countries to control and monitor suspicious funds transfers that do not have complete information.

In this connection, he spoke with UN Secretary General Ban-Kimoon's speech, noting that social media are being exploited not only for radicalization and recruitment but also for money collection. Other organizations around the world, from Boko Haram to Al-Shabaad and the Taliban, follow the same path. It is the offer of historical and cultural assets taken by extremists in social networks.

Another latent threat is cyber terrorism, which, according to Denning (2000, p. 143), is the attack or attempt to attack the computer network and the information contained therein by the Internet in order to intimidate or constrain it to achieve political or social goals. 
Its objectives, in addition to online communications, also include electrical, banking and financial systems, civil aviation, trains and metro. In the case of attacks on banking and financial systems, they strengthen the paralysis of services with incalculable economic losses. This has become possible due to easy access, speed, apparently anonymous nature of operations and various hiding possibilities.

Villamarín (2005, p.38) states that sustained by innumerable advantages facilitated by new technologies, small and large daily capital transit through the Internet to target tax havens through the electronic network that is accessible to anyone, anywhere in Worldwide, Facilitates anonymity and allows immediate transactions and cost savings.

According to Pinto (2007, p. 120), new information technologies through digital telecommunication, combined with the removal of geographical barriers, cost reduction, simplification of purchasing and selling processes and online money transfer services, favored money laundering.

According to the author, the proliferation of software programs makes the people interested completely anonymous and this is not only possible for the user but also for the service provider, which means that the tracking of the operation will be virtually impossible.

And the best thing for criminals is there is no face-to-face contact, no question, no inconvenience. It is an environment that requires international regulation or, soon, criminals will no longer need tax havens.

In the same vein, Dallagnol (2011, p. 376) broadens the discussion by adding that the Internet, in its turn, is currently an extremely important tool for exchanging information for ordinary citizens as well as for individuals and terrorist groups.

In 2007, the UK condemned three people in the country who used illicit home values to keep dozens of websites that incited martyrdom through terrorist acts. The Internet has been used, as can be seen, both to raise funds and to wash them, as well as to apologize and spread terrorism.

With regard to detection capabilities, given the new technologies available for monitoring, Naim (2011, p.137) is skeptical when arguing that wire transfers and other banking facilities made it possible for money laundering brokers, the division of their possessions in unsuspected parts, an essential first step for the success of an operation. Remote access from banks, with electronic cards, telephone, Internet, allows even more discretion and concealment. Despite the strong new technology available to power agencies to monitor these transactions, capturing those who need to be captured is almost impossible.

Saviano (2014, p.275) also confirms Naim's view that it is extremely difficult to get a money laundering case as well as the nature and degree of neglect of standards. "It's almost always like holding a hand of sand in your hands: grains always end up getting away."

In view of this situation, it is clear that, although information technology plays an important role in international society, this is paradoxical, particularly with regard to the issue of international terrorism, in particular money laundering.

At the same time, these are tools used to identify, locate and neutralize money laundering by electronic surveillance, where they are also most used by offenders and support networks to initially carry out illegal money transfers.

Also, with every attack by the financial intelligence agencies, new technological mechanisms appear to elude the attempt to control it. 


\section{Conclusion}

Considering the above, it is concluded that although the concentrated effort of governments and international community bodies to combat the various sources of terrorist financing, the problem persists but has not increased.

It is worth noting that, and even with the systematic development of new and more advanced programs and systems that allow the exchange of data and information, the analysis of large volumes of such data, storage and real-time communication between government agencies and Financial Intelligence ) investigating this type of offense, the difficulties in financing terrorism have shown unsatisfactory progress.

The biggest example of this is the significant funds raised by the Islamic state terrorist group, which allows it to expand its activities and fund attacks in different countries.

In the case of digital technologies, money laundering tools and other related crimes that favor terrorist groups in search of resources, it can be said that their development takes place faster than measures capable of protecting the financial system from illicit capital.

Allied to this situation, the corruption of state and private agents that prevents the identification of illicit assets bypassing control and supervision mechanisms is added to certain business financial firms that act on the brink of the law.

Corroborates the meaning of the relative effectiveness or control measures of partial disclosure in 2015 by the State Department of the United States in its Special Report on Country Reports on Terrorism with data showing a significant increase in the number of deaths caused by terrorism in $81 \%$ in 2014 compared to the previous year.

However, it draws attention to the fact that this significant increase in terrorist acts and the resulting side effects are concentrated in regions facing serious internal armed conflicts involving countries such as Iraq, Syria, Afghanistan and Nigeria, whose funding is with greater emphasis, with countries that support political and strategic interests.

What is clear in this environment is that the war on terror launched by former US President George W. Bush after September 11 lasts for fifteen years, and during this period new terrorist groups, larger and more sophisticated weapons arsenals, robust, clear recruitment techniques through ideological propaganda sites and links with criminal organizations.

These actions are possible with significant financial resources, continue to support the prolonged terrorist apparatus, fact demonstrates the inefficiency of the legal instruments proposed so far or even points to the possibility of inefficient cooperation of some UN member states.

An important point to be made is how the flow of resources continues to run into the hands of terrorist networks, although a significant number of rules, regulations, co-operation agreements, treaties and conventions are trying to reduce international terrorism? Is there a case of non-compliance with these standards, deficiencies in inspection and control, state exemptions of asset flow reduction in their financial markets or corruption?

Indeed, such a regulation does not fill the gaps that the criminal law system required for criminalizing behavior or align the recommendations of the international body.

Faced with this context, it is clear that the identification, blocking and confiscation of terrorist financing resources, although difficult to overcome by the difficulties to reach an international standard in all conceptual controversies about terrorism in the United Nations, strong that the use of the war machine, which proves to be unproductive, because terrorism 
intensified with dynamism, fueling a cycle of violence and uncertainty in the process.This is why it is the biggest challenge for international authorities.

Their greater or lesser effectiveness depends on human life, respect for the protection measures provided for in mechanisms for the promotion of human rights and international protection and, ultimately, the establishment of general security for the next decades.

\section{References}

BECHARA, Fábio Ramazzini, and MANZANO, Luis Fernando de Moraes, Organized Crime and terrorism in the United States of America. In: Organized Crime: procedural aspects,

FERNANDES, Antonio Scarance, MORAES, Maurício Zanoide, (et, al.) (Coord), São Paulo, Revista dos Tribunais, 2009.

BUZANELLI, Márcio Paulo. Because it is necessary to typify the crime of terrorism in Brazil. Revista Brasileira de Inteligência, no. 8, Brasília / DF, Brazilian Intelligence Agency, 2013.

BRAZIL. Constitution of the Federative Republic of Brazil of 1988. Available at: http://www.planalto.gov.br/ccivil_03/constituicao/ConstituicaoCompilado.htm. Accessed on 11.01.2019.

CASTELLS, Manuel. The galaxy of the internet: reflections on the internet, business and society, translation Maria Luiza X. De A. Borges; review Paulo Vaz, Rio de Janeiro: Zahar, 2003.

FINANCIAL ACTIVITIES CONTROL COUNCIL - COAF. Available at: https://www.fazenda.gov.br/coaf/portugues/publicações/cartilha.htm. Access on 19.11.2018.

COUNTRY REPORTS ON TERRORIS. Available at: http://www.state.gov/documents/organization/225045.pdf. Accessed on 22.12.2018.

CRETELLA NETO, José. General theory of international organizations. 2nd edition. Publisher Saraiva, São Paulo, 2007.

DALLAGNOL, Deltan Martinazzo.Financing of terrorism. In: DE CARLI, Carla Verrissimo, Money Laundering: prevention and penal control, Legal Verb, Porto Alegre, 2011.

DENNING, E.D. Cyberterrorism - Testimony before the Special Oversight, Panel on Terrorism Committee on Armed Services, U.S. House of Representatives, 2000.

Available at: http://www.cs.georgetown.edu/ denning/infosec/cyberterror.html. Accessed on 22.11.2018.

FEDERAL BUREAU OF INVESTIGATION. Available at: http://www.fbi.gov, Access on 25.12.2018.

FINANCIAL ACTION TASK FORCE / GROUP D 'ACTION FINNANCIÈRE, Available at: http://www.fatfgafi.org/media/fatf/documents/reports/FATF\%20Standards\%20\%20IXSpecial\%20R ecomendations\%20and20IN\%20rc.pdf Accessed on 10.01.2019.

GOMES, Rodrigo Carneiro. Organized crime in the vision of the Palermo Convention, 2nd edition, Belo Horizonte, publisher Del Rey, 2009.

LIMA, Renato Brasileiro de. Special Criminal Law Commented, Editors Jus Podivm, SalvadorBahia, 2014. 
LYMAN, Michael D. and POTTER, Gary W. Organized crime, 4th edition, New Gersey, Pearson Prentice Hall, 2007.

MAIA, Rodolfo Tigre. Money laundering - laundering of assets arising from crime: Annotations to the criminal provisions of Law No. 9.613 / 98. São Paulo, Malheiros Publishing House, 2004.

MACHADO, Marta Rodriguez de Assis and GONÇALVES, Guilherme Leite. By a state anti-terror law. Or there will be no one left. Revista Le Monde Diplomatic Brasil, year 9, no 101, 2015, p.22.

NAIM, Moses. Ilicit: the attack of piracy, money laundering and trafficking in the global economy,.

UN. Resolution No. 1,566, of October 8, 2004, of the United Nations Security Council.

PAMPLONA, Gustavo. Political crimes, terrorism and extradition: in the footsteps of Hannah Arendt, Porto Alegre, Simplissimo Publishing House, 2011.

PINTO, Edson. Money laundering and tax havens. São Paulo, Atlas, 2007.

SAVIANO, Roberto. ZeroZeroZero, translation Federico Carotti (et.al ...) São Paulo, Companhia das Letras, 2014.

SANTOS, Monique Soares dos. Criminal mechanisms to prevent forms of terrorist financing diversification, USP, Ribeirão Preto, 2014.

SCHIMID, A: In: SHANTY, Frank Misha; PABAN Patit. Organized Crime: from trafficking to terrorism, Santa Barbara, USA: ABC - CLIO, 2007.

VEDANTAM, Shankar. When Violence Disguises Virtue. In: Sverre Varmin and Varnik D. Volkan. (orgs). Violence or Dialogue? psychoanalytic reflections on terror and terrorism. Translation by Tânia Maria Zalcberg. São Paulo: Perspectiva, 2008.

VILLAMARÍN, Luis Alberto, Al Qaeda Connection: from Redist Islamism to Nuclear Terrorism, editions Nowtilus, S.L, 2005, Madrid., Narcoterrorism: the war of the new century, editions Nowtilus, S.L., 2005, Madrid.

VILLARÁN, Fernando. The lost paradises. In: VALCÁRCEL, Darío, Foreign Economics Review, Foreign Policy Studies S.A, Hidden Money, no49, Madrid, 2009, p.45.

WELTER, Antônio Carlos. The Criminal Control of money laundering: of crimes, basic dogmatics. In: CARLI, Carla Veríssimo Di and MENDONÇA, Andrey Borges (Coord) Money laundering: prevention and penal control. Editora Verbo Jurídico, Porto Alegre, 2011.

WOLOSZYN, André Luís. Global Terrorism: general and criminal aspects, Rio de Janeiro, Army Library Editora, 2010. 